Nevenka Bogataj

\title{
VZGOJA IN IZOBRAŽEVANJE ZA TRAJNOSTNI RAZVOJ ŠIRITA RAZUMEVANJE JAVNEGA INTERESA V IZOBRAŽEVANJU ODRASLIH
}

\section{POVZETEK}

Javni interes je izhodišče za strateške usmeritve izobraževanja odraslih (IO) v Sloveniji, a trenutno v njem manjkajo okoljske teme. To vrzel v upoštevanju izobraževalnih potreb in skupin predstavljamo s ciljem dopolniti sistemske dokumente ter utemeljiti vzgojo in izobraževanje za trajnostni razvoj (VITR) kot strateško prioriteto. Z uporabo kvalitativne metodologije smo analizirali najnovejše dokumente in druge vire iz obdobja 2010-2020 s treh vidikov: sistema, raziskovanja in prakse. Ugotavljamo, da nepoznavanje, neupoštevanje in nezanimanje za VITR ovirajo njegov razvoj. Z VITR lahko izobraževanje odraslih postane vključujoč ter na potencialih in prednostih ciljnih skupin utemeljen proces. Trenutna usmeritev $v$ povečanje temeljnih zmožnosti in okoljske zavesti z javnoveljavnimi programi in promocijo ne zadostuje za razvoj kritične andragoške prakse in sinergij med akterji, ampak velja začeti več (in drugačne) raziskave in preoblikovati sistem iz hierarhičnega v krožnega. Širše razumljen javni interes zato ne izključuje, ampak le dopolnjuje trenutno zastavljeno prihodnje desetletje slovenskega izobraževanja odraslih.

Ključne besede: javno, skupno, okolje, trajnost, vzgoja in izobraževanje za trajnostni razvoj

\section{EDUCATION FOR SUSTAINABLE DEVELOPMENT ENHANCES PUBLIC INTEREST IN ADULT EDUCATION - ABSTRACT}

Public interest is the starting point for strategic guidelines in adult education in Slovenia, yet this currently does not include environmental topics. By highlighting this gap in reflecting educational needs and target groups, the article's goal is to upgrade strategic documents and establish education for sustainable development (ESD) as a strategic priority. Qualitative methodology was used to analyse the most recent documents from three perspectives (system, research, practice). Evaluation criteria from 2020 are used to show that poor knowledge and interest in ESD limit its development. However, ESD can enhance adult education and turn it into an inclusive process based on the potential and advantages of its target groups. Current targeted public educational programmes for increasing basic competences and raising environmental consciousness are insufficient for developing critical andragogical practices and synergy among the relevant actors. More (and other forms of) research is needed, as is reframing

Dr. Nevenka Bogataj, Andragoški center Slovenije, nevenka.bogataj@acs.si 
the current hierarchical system into a circular one. Public interest in the broad sense therefore does not exclude but in fact complements the current framing of Slovenian adult education in the next decade.

Keywords: public, common, environment, sustainability, education for sustainable development

\section{UVOD}

Javni interes za naravo, okolje in koncept trajnosti se v Sloveniji razvija že od začetka 20. stoletja dalje. Izvorno in celo že v 19. stoletju je bila to skrb domačinov za izjemne dele narave (npr. Rajhenavskega pragozda, Doline Triglavskih jezer, planike in Blagajevega volčina) (Skoberne, 2018). Uničujoč vpliv industrije v 60. in 70. letih (npr. topilnice svinca v Žerjavu, celjske cinkarne, jeseniške železarne in drugih industrijskih obratov) je sprožil upor, nastanek Zakona o varstvu narave in preobrazbo okoljskih vprašanj v razvojne dileme. Desetletje zatem je ob občutnejšem vplivu povezovanja z Evropo in uveljavljanju globalizacije nastal koncept trajnostnega razvoja, ki terja premike tudi v politiki, zlasti pravičnost, sodelovanje, konsenz o družbenoekonomskem razvoju in preobrazbo iz hierarhičnih v krožne sisteme (Anko idr., 2007; Polajnar Horvat idr., 2014; Sedmak, 2009, str. 33). Zaradi neuspešnega reševanja okoljskih izzivov nov poskus preseganja antropocentrizma, instrumentalizacije narave in dihotomij (npr. razviti-nerazviti, aktivni-pasivni, stari-novi, Sever-Jug itd.) išče navdih pri avtohtonih ljudstvih, ki ne ločujejo človeka od narave življenja (Burns, 2018; De Angelis, 2018; Tengö idr., 2017). Med ključnimi tujimi avtorji na področju VITR je npr. nekdanja vodja ekspertne skupine UNESCO za spremljanje in evalvacijo VITR Tilburyjeva (2015) VITR nadgradila iz okoljskega izobraževanja v celostno spoznavanje posameznika in skupnosti (ne družbe), njuno transformacijo z učenjem, razvila pa je tudi nove kriterije in kazalnike ter jih naslonila na obči javni interes (Lange, 2019). V Sloveniji tako razumevanje VITR ni novo, saj se je razvijalo tudi samoniklo in prej (Anko idr., 2007; Marentič Požarnik, 2014; Piciga, 2017, 2020). Nismo torej zamudniki in sledilci, ampak na tem področju nosilci razvoja.

\section{OPREDELITEV PROBLEMA}

VITR v Sloveniji je danes mednarodna obveza države kot podpisnice Pariškega sporazuma (12. člen). Vključujejo ga številni strateški dokumenti, npr. Strategija razvoja Slovenije 2030 (Služba vlade za razvoj in evropsko kohezijsko politiko, 2018), ki v svojem cilju št. 2 terja uveljavljanje trajnostnega razvoja, aktivnega državljanstva in etičnosti, in Nacionalni program varstva okolja do leta 2030 (ReNPVO, 2020, v Piciga, 2020), ki v poglavju 8.6 določa VITR kot širši okvir vzgoje in izobraževanja za varstvo okolja in »okoljsko pismenost kot ključno sestavino funkcionalne pismenosti

V izobraževanju odraslih (IO) javni interes določata Zakon o izobraževanju odraslih (ZIO-1, 2018) in Nacionalni program izobraževanja odraslih (NPIO) (Resolucija o nacionalnem programu IO v Republiki Sloveniji za obdobje 2013-2020 [Resolucija], 2013). 
O naravi in okolju ne govorita, omenjata pa pojem trajnosti. V uvodu Resolucije je v trajnosti nakazana priložnost: »iskanje zelenih rešitev je tudi razvojna priložnost «, med prednostnimi nalogami pa so »sinergije med cilji na gospodarskem, družbenem in okoljskem področju «, trajnost je navedena tudi med dolgoročnimi cilji, ponudbo programov in poudarki (Resolucija, 2013). Politično raven VITR v slovenskem izobraževanju obravnavajo Smernice vzgoje in izobraževanja za trajnostni razvoj od predšolske vzgoje do univerzitetnega izobraževanja (2007), žal pa zanje ni raziskovalne podlage. Pilotne analize so nastale kasneje (Gobbo, 2011; Sedmak in Trnavčevič, 2009) ter so se nanašale zlasti na učitelje in kurikule zunaj IO. Za odrasle obstaja priložnostna analiza izkušenj in razumevanja tega področja (Združenje izobraževalnih in svetovalnih središč Slovenije [ZISS], 2019). Bogatejša in redna so konceptualna razmišljanja o VITR (Anko, 2013; Anko idr., 2007; Bogataj idr., 2016; Kleč, 2020; Marentič Požarnik in Silan, 2015; Piciga, 2020). V uporabi so različna izobraževalna orodja: dva izobraževalna programa (Anko idr., 2007; Bogataj idr., 2016), dve učni gradivi - Berilo o trajnosti (Anko idr., 2009) in Znamenja trajnosti (Bogataj, 2013a), metodološke usmeritve (Erčulj idr., 2010; Ličen, 2015; Ličen in Bolčina, 2011) in spletna orodja (e-učilnica evropskega projekta CIA2SFM, ${ }^{1}$ spletna stran znamenjatrajnosti.si). VITR je bil promoviran z dogodki in izdelki (Anclin, 2020; Posoški razvojni center, 2016; Rejec, 2008, 2009; Rejec in Kutin, 2014; Rejec idr. 2013; ZISS, 2019).

VITR v IO je torej v praksi živahen, razmeroma šibak in tog pa na sistemski ravni. To pravzaprav niti ne preseneča glede na ugotovitve literature (Anko, 2013; Gobbo, 2011; Marentič Požarnik in Silan, 2015) in hierarhično državno upravljanje, za katerega spremembe, sodelovanje in razvojni konsenz vsaj večinoma niso tipični (Pais in Provasi, 2015). Obstoj VITR v IO in rastoče potrebe deležnikov, kot so Znanstvenoraziskovalni center Slovenske akademije znanosti in umetnosti, Ministrstvo za okolje in prostor, Zveza izobraževalnih in svetovalnih središč Slovenije, kažejo vse večjo splošno potrebo po VITR, kar je v nasprotju z le projektno podprtim razvojem z evropskimi sredstvi in sredstvi Ministrstva za okolje in prostor (npr. Bogataj idr., 2016; Ličen, 2015). Manjka ugotavljanje izobraževalnih potreb in razvoj novih metodoloških pristopov in izobraževanj, zato je IO doslej minimalno - če sploh - prispeval k omejevanju razsipnosti s surovinami in energijo, torej k znižanju ekološkega odtisa, ki je v Sloveniji z 5,1 globalnega hektara višji kot v Evropi $(4,6)$ in na svetu $(2,7)$ (Piciga, 2020). Ker to omogočajo ugodne naravne okoliščine, npr. velik delež gozdov, ki so ponor ogljika, razpršena poselitev, ki prebivalcem omogoča neposreden stik z naravo in zaradi zasebnega lastništva tudi osebno izkušnjo gospodarjenja z zemljišči, gre za krhke ter vse ohlapnejše varovalke, saj se podnebje segreva, družba pa se je urbanizirala. Priložnostna analiza (ZISS, 2019) je sicer nakazala vračanje spoštljivosti do kmeta in podeželja kot potencialnih nosilcev zdravega življenjskega sloga ter omogoča vpogled v stanje, toda za razvoj je nujna enotna predstava o VITR in njegovih referenčnih točkah. A številna srečanja odločevalcev, strokovnjakov in praktikov v letu 2020 (Delovna srečanja predstavnikov javnih zavodov za sodelovanje v projektu Deep Demonstration

1 Cooperation for innovative approach in sustainable forest management (http://cia2sfm.sumins.hr/). 
[Delovna srečanja], 7. 5.-30. 6. 2020) kažejo, da je predstava o VITR neenotna in da so referenčne točke zanjo razpršene.

Ta sistemska ovira za hotén in sistematičen VITR je okrepljena s promocijo globalnega učenja, ki ga je UNESCO (1974) priporočal v 70. letih, mednarodni strokovnjaki »vrnili« političnim odločevalcem (Manion idr., 2011), z leti pa se skupaj z mednarodnimi strategi usmerili v boljši stik z lokalnimi okolji (Boeren, 2019; International Council for Adult Education [ICAE], 2020; UNESCO Institute for Lifelong Learning [UIL], 2020). Ker so referenčne točke VITR mešanica področij (kakovost, inovacije), načel (aktivnost, družbena odgovornost), ravni in metod (recikliranje, učenje na prostem, skupinske metode dela), ni dovolj omemba Agende 2030 v strateškem dokumentu za IO ter ohranjanje dosedanje zasnove in razmišljanja tudi v naslednjem desetletju. IO zmore, sme in celo mora sprejeti smelejše spremembe, četudi trenutno kaže, da bo javni interes usmerjen bolj v bralno kot $\mathrm{v}$ okoljsko pismenost in VITR. Še naprej ne bo jasno, ali formalna izobrazba, znanje, kompetence, pismenosti in veščine prispevajo k ohranjanju zraka, pitne vode in prostora kot temeljnih dobrin, od katerih smo odvisni vsi in so po definiciji skupna in ne tržna dobrina. Želimo, da se javni interes izobraževalcev odraslih razširi, preseže trenutnega sektorskega in se izenači z interesom državljanov.

VITR spodbuja in terja soustvarjanje, izkušenjsko učenje in nehierarhično organizacijo za vzdrževanje notranjega ravnotežja ob odzivanju na zunanje vplive. Tudi v naravi velja enako, ker je tako poraba energije minimalna, kar pa (̌se) ni gonilo organiziranosti današnje družbe in njenih institucij. Prilagajanje spremembam je (zato?) počasno in polno trenj. Javna mreža izobraževalcev odraslih skupaj z drugimi ponudniki učenja je bolj vajena standardiziranih administrativnih postopkov kot policentrične organizacije, tipične za koncept trajnosti (Bogataj, 2013b; Ostrom, 1990). Zato je digitalizacija pomembna, ni pa nadomestilo za krožne procese z nizkim ogljičnim odtisom. Le recipročno delovanje je vključujoče in hkrati zajema vse tri vidike trajnosti (ekologijo, družbo in ekonomijo) (Maček, 2013; Pais in Provasi, 2015), zato utegne počasna preobrazba družbenoekonomske organiziranosti Matejev efekt rastoče udeležbe bolje izobraženih vsaj nekaj časa še dalje povečevati, številni izobraževalni programi, gradiva in spletne platforme pa ostati koristen, a ne zadosten pogoj za VITR. V nadaljevanju iščemo argumente za pospešitev oblikovanja organizacijske kulture, ki bi omogočila VITR v okviru razširjenega javnega interesa tudi v IO.

\section{OKVIRNI PREGLED STANIA NA PODROČJU VITR}

Mednarodno in s tem tudi slovensko izhodišče za opredelitev VITR je razhajanje med omejenimi naravnimi viri in načelom rasti, ki usmerja organizacijo gospodarstva. Državno reševanje nasprotja med ekonomskimi in ekološkimi načeli je bilo v ospredju v 60. letih, o čemer govorita klasični deli na tem področju Nema pomlad (Carson, 1972), ki je v izvirniku izšlo 1962, in Tragedija skupnega pašnika (Hardin, 1968). Toda usklajevanje med ljudmi poteka tudi zunaj državnih institucij in upošteva okolje, je 
ugotovila Ostromova (1990), nagrajena z Nobelovo nagrado za ekonomijo. Posledično je bila priznana ključna vloga lokalnih skupnosti za uveljavljanje koncepta trajnosti, ki prihaja v globalne strateške dokumente IO šele po treh desetletjih (ICAE, 2020; UIL, 2020), v slovenske strateške dokumente pa vsaj trenutno še ne. Prvotnemu kompromisu med ekonomijo in ekologijo je sledilo njuno zbliževanje npr. v konceptih varčevanja $\mathrm{z}$ energijo in kroženja snovi, kar za tradicionalne gospodarske enote na najnižji ravni kmetije - ni nobena novost, v izobraževanju pa postaja prioriteta strank in gibanj (npr. za podnebno pravičnost) pa tudi Združenih narodov z Agendo 2030. Strokovna literatura kritizira neupoštevanje kulturne pestrosti $\mathrm{v}$ globalnih in nacionalnih dokumentih (Koulaouzides in Popović, 2017; Popović, 2018; Virtanen idr., 2020), slabo vodenje in institucionalizacijo VITR kot vseživljenjskega učnega procesa. Neučinkovite implementacije dosedanjih strateških dokumentov nekateri pojasnjujejo s hierarhijo moči, npr. »največ izgube tisti, ki imajo največ« (Anko, 2013, str. 17). Medtem netrajnostna raba naravnih virov vodi v pomanjkanje in posledično iskanje dodatnih virov (npr. v vesolju) in sodobnejših tehnologij (npr. hidravlično drobljenje (fracking) za črpanje nafte, ki je bilo v Lendavi z vladno intervencijo preprečeno). Nadaljujejo in krepijo se konflikti zaradi nafte na Bližnjem vzhodu, vode v Afriki in žlahtnih kovin v Južni Ameriki. Evropsko gospodarstvo skuša družbene dileme razrešiti z bližanjem konceptu trajnosti in njegov del je tudi Slovenija.

VITR obsega različne vsebine in pristope:

- instrumentalni (tudi konservativni ali plitki), ki pričakuje spremembe šele z več znanja in občutljivosti,

- emancipatorni (tudi radikalni ali globoki), ki terja spremembo ravnanja in opolnomočenje.

Ključni globalni akter za VITR je UNESCO, katerega diskurz iz »boja proti«, prek »prilagajanja in blaženja «, globalnega učenja in državljanstva za odpravo revščine in medgeneracijsko pravičnost (UNESCO, 1974) prehaja $\mathrm{v} »$ razumevanje sistemov«, »trajnostno pismenost « in transformativno učenje (ICAE, 2020; UNESCO, 2017; UIL, 2020). Ti dokumenti terjajo preusmeritev socioekološkega sistema kot celote s pomočjo že znanih konceptov, npr. transformacije. Transformacija naj bi bila ključna naloga odraslosti, do katere vodita vključujoč skupinski dialog in kritično vrednotenje. Za transformacijo ni pomembno le število sodelujočih, kar je najpogostejši kazalnik učinka izobraževanja ali prisotnost ekspertov kot npr. v formalnem izobraževanju, ampak je ključna konstrukcija dodane vrednosti. To je za IO priložnost, saj pozna in prakticira sooblikovanje interpretacije z udeleženci izobraževanj v Temeljnem usposabljanju za trajnostni razvoj, tudi v navezavi s konceptom državljanstva. Tradicije okoljskega izobraževanja, izobraževanja za razvoj in izobraževanja za državljanstvo so kot podlago za razvoj globalnega državljanstva preučili Manion in sodelavci (2011) in ugotovili, da gre za retoričen poskus združevanja tradicij, temelječih na zahodnem razumevanju civilne družbe, okolja in mednarodnega ekonomskega razvoja, ki ohranja prej omenjene dihotomije in ne more uveljaviti kritičnosti. VITR torej ne gre mešati z globalnim državljanstvom, lahko pa se med seboj dopolnjujeta. 
V slovenskem IO se med drugim kot ključni izzivi VITR pojavljajo neenotno razumevanje (kompleksnega) pojma, razpršene referenčne točke zanj in primanjkljaj raziskovalnih temeljev. Ne poznamo izobraževalnih potreb za razvoj VITR, dejavnikov vpliva na trajnostno vedenje, ne kazalnikov VITR, četudi okoljske spremembe trajajo že desetletja in se začenjajo kazati že v številnih ekstremih. Tuji predlogi, ki jih privzemamo (država pa tudi sofinancira), so ali pa tudi ne prilagojeni našim razmeram (npr. projekt Bridge 47, gl. https://bridge47.org/). Brez poznavanja okolja in njegovih povezav z ljudmi (npr. Bogataj in Krč, 2018) si celo iz ugotovljenih vplivov na izmerjena znanja (npr. izobrazba matere, količina branja) težko pomagamo razvijati VITR, saj okolje in odnos do njega v meritve nista zajeta. Tudi sicer ni enostavno preliti podatkov v izobraževalne vsebine in ciljne skupine. Koristile bi sinteze sistemov znanja, interdisciplinarne in transdisciplinarne povezave (Virtanen idr., 2020) ter poznavanje longitudinalnih trendov in motivov participacije in učenja odraslih.

V praksi primanjkuje izobraževalnih programov, ki obravnavajo ekosisteme, ravnovesja v naravi ter med naravo in družbo, časovno perspektivo ter vlogo biološke in socialne pestrosti. Kljub praksam, ki prispevajo k ohranjanju in razvoju lokalnih okolij ter integrirajo različne vloge posameznika, so redki programi za mešane ciljne skupine in izkušenjsko učenje. Eden takih programov so študijski krožki, ki pa so razviti za drug namen in ne kot orodje VITR. Spodbujanje avtonomije in medsebojnega sodelovanja lokalnih izobraževalcev za prilagajanje spremembam družbe in okolja hkrati bi bilo treba šele razviti in s tega vidika posodobiti obstoječe izobraževalne aktivnosti. Primanjkuje splošno sprejetih metodoloških prijemov za VITR, čeprav jih nekateri viri že navajajo (Erčulj idr., 2010; Jelen Mernik, 2016; Ličen, 2015). Prezrta lokalna znanja in tradicije niso le dediščina, ampak tudi zgled krožne organizacije, povezane z naravnim okoljem, saj jim ni tuje varčevanje z energijo, spoštovanje biološke in družbene pestrosti, nepredvidljivost ter dolgoročni obstoj. Zato je VITR velika priložnost, da seže izobraževanje (zlasti pa IO) dlje, kot sega zdaj. Izziv je verjetno predvsem preobrazba iz mehanistične zavesti v odnosnost, pomen in smisel na višjih ravneh organizacije, da bo mogoče VITR operacionalizirati (Lange, 2018).

\section{NAMEN ANALIZE}

Prvi namen analize je prispevati k boljši sistemski umestitvi VITR v nastajajoči nacionalni program izobraževanja odraslih za prihodnje desetletje (2021-2030) in tako spodbuditi $\mathrm{k}$ enotnejšemu razumevanju pojma VITR ter k vključitvi okoljskih in trajnostnih vidikov v sistem, raziskave in prakso. Pri tem VITR opredeljujemo kot proces, način, pot, orodje za obstoj in delovanje skupnosti ne le na nacionalnem teritoriju in ne samo kot končni cilj. Vanj vključujemo vse, ki so skupnosti pripadni (npr. Slovenci v zamejstvu in izseljenstvu) in so v skupnost voljni vlagati. Drugi namen analize je postaviti v ospredje nabor argumentov za doseganje zgoraj opisanega namena. Ne nazadnje želimo spodbuditi razvoj prakse, raziskovanja in sistema IO z vpogledom v nekatere dosedanje dosežke izobraževanja in z njim povezanih aktivnosti. 


\section{METODA IN VIRI}

Z metodo analize dokumentov (Vogrinc, 2008, str. 124) smo analizirali predvsem domače (Globalno učenje za spodbujanje trajnostnega razvoja v vzgoji in izobraževanju, 2012; Gobbo, 2011; Resolucija, 2013; Sedmak in Trnavčevič, 2009; Torkar, 2014; ZISS, 2019; ZIO-1, 2018), pa tudi nekatere pomembne mednarodne dokumente (ICAE, 2020; OECD, 2016; UIL, 2020), s poudarkom na tistih, ki so nastali v letu 2020 za izobraževanje. Analizirali smo tudi domače neobjavljene vire, ki se nanašajo na IO in VITR (Delovna srečanja, 2020; Fokusne skupine 1, 2, 3 in 4, 2020). ${ }^{2}$ Opazovane vidike in vire za vsako opazovano področje posebej (sistem, raziskave, praksa) prikazuje Preglednica 1 v poglavju Rezultati. Ta vključuje podatke fokusnih skupin in javnih posvetovalnih srečanj, ki jih je za pripravo Resolucije za obdobje 2021-2030 organiziral Andragoški center Slovenije v letu 2020 (Fokusne skupine 1-4, 2020), ter ugotovitve delovnih srečanj predstavnikov javnih zavodov v okviru Ministrstva za izobraževanje, znanost in šport (MIZŠ) o možnostih razvoja VITR, ki jih je v obdobju marec-december 2020 skliceval Sektor za razvoj izobraževanja na Uradu za razvoj kakovosti izobraževanja pri MIZŠ (Delovna srečanja, 2020).

Kriterije trajnosti smo privzeli po literaturi (Virtanen idr., 2020) in jih ocenili okvirno z naslednjimi simboli: pretežno dosežen kriterij (+), pretežno ni dosežen kriterij $(-)$, ni podatkov (?), nejasna zveza, težko oceniti (*).

Čeprav velja VITR razlikovati od koncepta trajnosti, je med konceptom ter vzgojo in izobraževanjem za njegovo doseganje jasna povezava: VITR prispeva $\mathrm{k}$ doseganju kriterijev trajnosti:

- Kontekstualna odnosnost je vedno lokalno specifična in nastane po metodi snežne kepe. Zato jo je za sistem težko enoznačno opredeliti, za raziskave pa se v tej analizi nanaša na podatke zadnje raziskave Program za mednarodno ocenjevanje kompetenc odraslih (PIAAC). Praksa je vedno kontekstualna, če vključuje deležnike in zajema vsebine in oblike VITR.

- Upravljanje v sistemu in raziskavah ni skupnostno, v praksi pa je lahko, a ne nujno.

- Izobraževanja, ki upoštevajo lokacijo in sodelovalno sintezo ter avtohtoni jezik kot izraz dinamičnih komunikativnih praks (npr. narečje).

- Kakovost življenja je v IO pomembna in upoštevana, saj je to eden od namenov IO oz. vseživljenjskega učenja.

- Transcendenca je iz izobraževanja prej iztisnjena kot zaželena, saj desetletja poudarjamo predvsem kognitivni vidik izobraževanja.

2 Fokusna skupina 1: 17. 6. 2020 v Ljubljani na zavodu Cene Štupar, MIZŠ (do 3), ACS (do 3), ZLUS, ZiSSS, FF UL, FDV, predmet razprave: podporne dejavnosti, vključno z raziskovanjem, vodil jo je dr. Andrej Kohont. Fokusna skupina 2: 18. 6. 2020 v Ljubljani na zavodu Cene Štupar, predmet razprave: 1. prednostno področje: neformalno IO, MIZŠ (do 3), ACS (do 3), ZLUS, ZiSSS, ADS, JSKD, CNVOS, U3ŽO, ZDUS (Jožica Puhar). Fokusna skupina 3: Posvetovalno srečanje za pripravo ReNPIO 2021-2030-ministrstva, 30. 6. 2020, Ljubljana, Radisson Blu, Plaza hotel; https://web.acs.si/renpio2021-2030/dogodek2020-1. Fokusna skupina 4: Posvetovalno srečanje za pripravo ReNPIO 2021-2030-deležniki in socialni partnerji, 15. 7. 2020, Ljubljana, Radisson Blu, Plaza hotel; https://web.acs.si/renpio2021-2030/dogodek2020-2. 


\section{REZULTATI}

\section{Sistem}

$\mathrm{V}$ tem poglavju predstavljamo opredelitev VITR in njegovo organiziranost oz. umestitev v Nacionalnem programu IO in Letnem načrtu dela ACS.

Koncept VITR se izmenjuje in prekriva s pojmi okoljsko izobraževanje, zeleno izobraževanje in globalno učenje (Delovna srečanja, 2020; Fokusne skupine 1-4, 2020; Globalno učenje za spodbujanje trajnostnega razvoja v vzgoji in izobraževanju, 2012). Temeljni strateški dokumenti IO pojem trajnost navajajo, a ga podrobno ne utemeljujejo, npr. z definicijo, dosedanjimi dosežki, načrti. Zakon o IO (ZIO-1, 2018) ne vsebuje pojmov »okolje« ali »narava«, trajnost pa omeni dvakrat: v 5. od 12 ciljev IO (»krepiti opolnomočenost na področju trajnostnega razvoja, zelenega gospodarstva, kulture in zdravja «) in v 21. členu, kjer govori o neformalnih izobraževalnih programih za odrasle. Njegov 7. od 11 vsebinskih poudarkov je »trajnostni razvoj in zeleno gospodarstvo«. Izobraževalne programe opredeljuje s pojmom »neformalni izobraževalni programi za odrasle« (ZIO-1, 2018).

Veljavni NPIO »nadaljnji razvoj VITR « navaja v poglavju Splošno neformalno izobraževanje kot novost in razvojno dejavnost (Resolucija, 2013). Med 11 poudarki oz. prednostnimi nalogami omenja »ozaveščanje o pomenu in usposabljanje za udejanjanje načel trajnostnega razvoja«, v 5. od 15 dolgoročnih ciljev pa je cilj »Spodbujati ljudi k delovanju, premisleku in ustreznemu odzivanju na socialne, politične, gospodarske, kulturne in tehnološke izzive ter h graditvi skupnosti po načelih trajnostnega razvoja« (Resolucija, 2013). Nastajajoči NPIO (Resolucija, 2020) pojem »trajnost « uvede z dokumentoma Strategija razvoja Slovenije 2030 in Agenda 2030 ter ga umesti med vsebinske prioritete. Omenja dosežke splošnega izobraževanja in nujnost promocije, nato pa med izhodišči za prihodnje desetletje navede le raziskavo PIAAC (OECD, 2016). Trajnost (predvidoma VITR) se ponovno pojavi v segmentu »splošno izobraževanje«, toda med podalinejami, kjer so naštete zmožnosti, oblike pismenosti ter »razvojne dejavnosti«. Zdi se torej, da bo VITR odslej podskupina oblik pismenosti, kar je novo in doslej neargumentirano. Izobraževalni programi so razvrščeni na različne načine, npr. glede na javno veljavnost v: 1. javno veljavne programe (16. člen) za dva namena (pismenost in splošno izobraženost) in 2. neformalne izobraževalne programe (z istima namenoma, ki jima jih je pridruženih dodatnih sedem) ali glede na namen (za trg dela, pismenost, splošno izobraženost), kjer se prav tako ločijo javno veljavni in ne javno veljavni programi.

Andragoški center Slovenije sledi Programu dela, v katerem je za leto 2020 (verzija 12. 8. 2020) trajnostni razvoj naveden pod nekoliko drugačnim naslovom kot v NPIO, in sicer »Neformalno učenje in izobraževanje odraslih«. Programoteka in spletna stran VITR umeščata med programe splošnega usposabljanja in spopolnjevanja, kot jih predvideva 6. člen ZIO-1 (2018), oz. med neformalne izobraževalne programe za odrasle, opredeljene $\mathrm{v}$ členih 21-23. ${ }^{3}$ Zadovoljuje lahko le posamični namen (npr. 7. alinejo: trajnostni razvoj in

3 Za pravni okvir študijskih krožkov kot strukturnega modela skupnostnega učenja, ki ga razvijamo več kot 25 let in bi ga veljalo zaradi dobrih rezultatov zakonsko zaščititi kot javno dobro, je bilo predlagano besedilo: »V podporo skupnostnemu učenju v lokalni skupnosti se odraslim omogoči učenje v študijskih krožkih. 
zeleno gospodarstvo) ali dva (tudi 5. alinejo: graditev skupnosti in delovanje v njej), lahko pa kar vse hkrati. Tudi v fokusnih skupinah (Fokusne skupine 1-4, 2020) in neformalnih razpravah (Delovna srečanja, 2020) je bilo očitno neenotno razumevanje VITR, saj sta se pojma trajnost in izobraževanje za trajnostni razvoj pojavljala v povezavi s cilji, dejavnostmi in interesi sodelujočih (globalno učenje, spodbujanje podjetništva, učenje na prostem, upoštevanje dediščine v izobraževanju itd.).

\section{Raziskave in analize}

Mednarodna raziskava PIAAC (OECD, 2016) med 1350 vprašanji ne vsebuje nobenega podatka o naravnem okolju in njegovi rabi. Zato ni dobra podlaga za opredelitev raziskovalnih potreb na področju VITR, kar smo tudi preizkusili ob ovrednotenju socialnega kapitala za izbrano ciljno skupino in ugotovili, da kazalci »skupnostnega« delovanja $\mathrm{k}$ VITR zaradi odsotnosti povezav z okoljem ne morejo prispevati.

Analize, ki vključujejo odrasle, se nanašajo na šolski kurikul in stališča učiteljev, zlasti srednješolskih (Gobbo, 2011; Sedmak in Trnavčevič, 2009; Torkar, 2014). Razmeroma enotno ugotavljajo, da anketirani VITR razumejo kot pomemben vseživljenjski proces, ki ga po svojih močeh že vključujejo v pouk, a področja ne poznajo, zato je VITR odvisen od zavzetosti posameznika. Želijo si usposabljanj, prakse, didaktičnih gradiv in smernic (Sedmak in Trnavčevič, 2009). Anketa in akcijsko raziskovanje potencialov, vrzeli ozaveščanja, znanja in aktivnosti VITR v IO (ZISS, 2019) sta pokazala prisotnost VITR v študijskih krožkih, na delavnicah in promocijskih dogodkih, prepuščenost samoiniciativi izvajalcev, posamične zglede in izobraževalne aktivnosti ter željo po smernicah in financiranju tega področja. Glede usposobljenosti so bili sodelujoči mnenja, da niso povsem neusposobljeni, ampak so za VITR delno usposobljeni, ker so si vsaj površinska znanja pridobili z lastnim zanimanjem in posamičnimi izobraževanji. Pomoč pričakujejo zlasti pri vključevanju VITR v programe in vsebine $(57 \%)$, pri možnostih za dodatna usposabljanja (57 \%) in materialni podlagi za razvoj VITR (40\%). Zanimive so njihove ugotovitve o tem, ali z VITR lahko vplivamo na vedenje ljudi in kaj bi bilo treba storiti za to (ZISS, 2019). Ugotovitve navajamo v zaporedju po njihovem pomenu, kot so ga opredelili anketiranci (ZISS, 2019):

- organizacijski vzorci višjih ravni so netrajnostni, npr. mobilnost, ki bi jo udeleženci zelo radi spremenili v trajnostne oblike (vlak, kolo itd.), česar pa sami ne morejo;

- poenostavljeni in enoznačni motivi, kot sta »strah za prihodnost« ali »varčnost«, niso zadostni, ker npr. samooskrba (z oblačili, semeni, hrano) ni vedno cenejša od obstoječe oskrbe, ampak je smiselna le v kombinaciji z drugimi motivi (npr. kakovost, osebni vpliv na razvoj in uporabo veščin);

- spreminjanje ravnanja mora biti prilagojeno konkretnemu okolju in ne na ravni splošnih usmeritev;

\footnotetext{
Študijski krožki, ki jih ureja ta zakon, morajo biti organizirani tako, da omogočajo povezanost učenja s spremembami v okolju [...] s čimer bi opredelili strukturo, hkrati pa tudi kadrovske pogoje za izvajanje te oblike skupnostnega neformalnega izobraževanja odraslih ter prispevali k opredelitvi minimalnih normativnih standardov kakovosti za njihovo izvajanje, če so financirani iz javnih sredstev« (Možina, 2019, str. 23).
} 
- posebnosti programov VITR glede na ponudbo učenja jezika ali IKT so v lokalno specifičnih možnostih, ki jih je veliko, kar omogoča, da je udeleženec soustvarjalec praktičnih in uporabnih rešitev, ne pa objekt za npr. transmisijo vsebin;

- potrebna je povezanost vsebine in aktivnosti s ciljno skupino ter hkrati s konceptom trajnosti kot takim ali pa s konkretno aktivnostjo, ob kateri razvijamo razumevanje načel trajnosti;

- multiple vloge vodje in izvajalca VITR terjajo usposabljanje, ki presega kognicijo, saj so poleg vsebinskih referenc potrebne tudi čustvene in socialne kompetence in reference.

\section{Praksa VITR}

\section{Izobraževalni programi}

Prva izobraževalna programa za VITR v IO je razvil Andragoški center Slovenije. Prvi, Temeljno usposabljanje za trajnostni razvoj (Anko idr., 2007), je bil ponujen tudi učiteljem, in sicer z umestitvijo v Program stalnega strokovnega izpopolnjevanja učiteljev leta 2012, drugi, Razširjeno temeljno usposabljanje za trajnostni razvoj in zeleno gospodarstvo v povezavi s podnebnimi spremembami (Bogataj idr., 2016), pa predvsem vodstvenim in strokovnim delavcem v IO. Izobraževalna programa Gradimo za jutri (2014) in Obnavljamo staro za novo kakovost bivanja (2019) sta nastala v okviru Posoškega razvojnega centra. Med ljudskimi univerzami so na področju VITR izstopajoče UPI Žalec, ki je z ambicioznimi študijskimi krožki, npr. Tri, dva, ena-priložnost za trajnost še ni zamujena, povezovala deležnike (lokalno skupnost, razvojno agencijo) in znane okoljevarstvenike (Anclin in Križnik, 2018), Ljudska univerza Ajdovščina (LUA), ki je razvila program Zdravo za nas in naravo in v okviru Centra medgeneracijskega učenja spodbuja omejevanje količine odpadkov in uporabo naravne kozmetike, ter Ljudska univerza (LU) Slovenska Bistrica, ki z uporabo električnega avtomobila javno promovira trajnostno mobilnost. Tudi nekateri drugi primeri kažejo potenciale za aplikacijo na področja, kot so prehrana, mobilnost, oblačenje, raba vode, organizacija pisarniškega dela, javnega naročanja, učenje iz zgledov in uveljavljanje samoorganizacije (Bogataj, 2013b; Kleč, 2020; Resnik Planinc in Ogrin, 2017).

\section{Učna gradiva in publikacije}

Učno gradivo Berilo o trajnosti (Anko idr., 2009), posodobljeno z naborom domačih primerov dobre prakse (Bogataj, 2013b), je v širši uporabi tudi zunaj IO. Zbirnik in utemeljitev skupinskih metod (Ličen idr., 2015) poudarjata povezavo VITR z dejavnostmi, veliko metodološko pestrost in vlogo »osvobajajočih socialnih praks«. Tudi drugi avtorji poudarjajo pomen skupinskih metod, debate, projektnega dela in pogovora ter transformativnega učenja, ki je »signifikantno« in »izkustveno« (Piciga idr., 2016; Sedmak in Trnavčevič, 2009, str. 106). Zanimiva je publikacija študijskega krožka Sivka (Mohorčič idr., 2017), ki sicer ni bila namenjena VITR, a bi jo vanj spričo njene celovitosti smeli umeščati. Domišljen in občudovanja vreden nabor publikacij redno nastaja v okviru Posoškega razvojnega centra (2016; Rejec, 2008, 2009; Rejec in Kutin, 2014; Rejec idr. 2013). 
Nedvomno je publikacij, projektov in promocijskih dogodkov še več in prav tako institucij, ki bi bile lahko referenčne za VITR, zato nas celovit pregled prakse še čaka.

\section{Spodbujanje, ozaveščanje in promocija}

Spletna stran znamenjatrajnosti.si povzema prvo učno gradivo in občasno javnost tudi informira. Podobno velja za občasne dogodke, npr. delavnice, predavanja in promocijske dogodke, med katerimi v ospredje postavljamo redno izvedbo Tedna izobraževanja za trajnostni razvoj. Inovativni so tako imenovana znanstvena dialoška srečanja, ki jih organizira Razvojno-izobraževalni center Novo mesto, ter učna dejavnost Ljudske univerze Ajdovščina v učnem centru na Brjah v Vipavski dolini (o samooskrbi s sadjem, kompetencah za prevzem kmetije). Vsaj tretjina študijskih krožkov raziskuje in posodablja dediščino ter razkriva temeljno povezavo skupnosti z naravnim okoljem, kar je odlično pokazala tudi razstava ob njihovi 25-letnici (Bogataj, 2018). Promocijske aktivnosti Andragoškega centra Slovenije se preobražajo v ozaveščanje ter se pri tem naslanjajo na projekt EPALE in pobude matičnega ministrstva (npr. za promocijo globalnega učenja).

\section{Zagotavljanje načela trajnosti v VITR}

\section{Preglednica 1}

Kriteriji trajnosti za predstavliene vidike izobraževanja odraslih

\begin{tabular}{|l|c|c|c|}
\hline Kriterij trajnosti & SISTEM & $\begin{array}{l}\text { RAZISKAVE IN } \\
\text { ANALIZE }\end{array}$ & PRAKSA VITR \\
\hline Kontekstualna odnosnost & 2 & - & + \\
\hline Skupnostno upravljanje & - & - & $*$ \\
\hline $\begin{array}{l}\text { Izobraževanje, ki upošteva lokacijo, } \\
\text { sodelovalno sintezo in medsebojne soodvisnosti }\end{array}$ & - & - & $?$ \\
\hline Jezik kot izraz dinamičnih komunikativnih praks & + & - & + \\
\hline $\begin{array}{l}\text { Kakovost življenja (zdravje, družbena } \\
\text { odgovornost) }\end{array}$ & + & + & + \\
\hline $\begin{array}{l}\text { Transcendenca (zgodbe, miti, prepričanja, } \\
\text { pripadnost, pričakovanja) }\end{array}$ & $\begin{array}{l}\text { ZIO-1, 2018; } \\
\text { Resolucija, } \\
2013 ; \\
\text { Resolucija, } \\
2020 ; \text { Fokusne } \\
\text { skupine 1-4, } \\
2020 ; \text { Delovna } \\
\text { srečanja, 2020 }\end{array}$ & $\begin{array}{l}\text { Spremenliivke } \\
\text { OECD (2016); } \\
\text { Fokusne } \\
\text { skupine 1-4, } \\
\text { 2020; Delovna } \\
\text { srečanja, 2020 }\end{array}$ & $\begin{array}{l}\text { Literatura v } \\
\text { poglavju Praksa } \\
\text { VITR }\end{array}$ \\
\hline
\end{tabular}

Legenda. (+) pretežno dosežen kriterii, (-) pretežno ni dosežen kriterii, (?) ni podatkov, nejasna zveza, (*) težko oceniti 
Preglednica 1 prikazuje tri vidike izobraževanja (sistem, raziskave in analize ter prakso VITR) skupaj z uporabljenimi viri in okvirno oceno doseganja kriterijev trajnosti (Virtanen idr., 2020).

Preglednica kaže, da so trije kriteriji trajnosti izrazito slabo doseženi: 1. skupnostno upravljanje; 2. izobraževanje, ki upošteva medsebojne soodvisnosti in ne le kognitivnih dimenzij znanja; in 3. upoštevanje transcendence $\mathrm{v}$ smislu pripadnosti prostoru in času bivanja $\mathrm{v}$ njem.

\section{RAZPRAVA}

VITR je v različnih oblikah in pod različnimi poimenovanji prisoten že več desetletij ter postopoma širi javni interes z varovanja izjemnih naravnih objektov in pojavov na prilagajanje družbe spremembam. Četudi so mednarodni in domači teoretiki, pa tudi UNESCO že pred slabim desetletjem poudarjali potrebo po transformativnem učenju, to danes $\mathrm{v}$ slovenski praksi IO obstaja le v sledovih in ob robu finančnih tokov, usmerjenih predvsem $\mathrm{v}$ zaposljivost in pismenost na podlagi argumenta socialnih primanjkljajev. Soodvisnosti $\mathrm{v}$ družbi in z naravo še iščejo razumevanje in svoje mesto v odločanju in ravnanju najbolj odgovornih za sistem IO v Sloveniji. Iskanje navdiha se iz tujine preusmerja v lastno dediščino, saj avtohtona ljudstva celovitosti družbe in narave niso nikdar pretrgala, kar smo v izbiri kriterijev v tem prispevku upoštevali. Preobrat se zdi v Sloveniji prepleten s politično voljo in splošnim ustrojem gospodarstva, zato ne preseneča, da se proti enotnemu razumevanju VITR še prebijamo. V praksi imamo zanj precej prednosti, kot so struktura poselitve, tradicija gospodarjenja z zemljišči in zanimanje posameznikov in institucij za okolje. Toda VITR je hkrati ujet $\mathrm{v}$ sistemsko razsipnost $\mathrm{s}$ surovinami in energijo ter skrajno počasen odziv nosilcev odločanja na dosedanje izobraževalne pobude in potrebe okolja. Ne vemo pravega razloga za to, da je bil VITR doslej v izobraževanju in v IO dopuščen, ne pa tudi sistemsko podprt ter da ostaja tudi za prihodnje desetletje (do izteka leta 2030) v strateških dokumentih le omenjen, ne pa tudi razvit in razvejen. Usmeritev IO v primanjkljaje in marketing že dve desetletji te vsebinske vrzeli ni odpravila, kljub mednarodnim obvezam za to. Sistemski okvir »splošno in neformalno izobraževanje«, kamor je VITR v IO umeščen, ni čvrst, saj se njegova naslovna pojma pojavljata izmenično, včasih pa skupaj, za zdaj pa brez širšega konsenza o njegovi vsebini in zasnovi. Brez raziskovalne podlage, npr. podatkov o izobraževalnih potrebah, je VITR v neenakem položaju z drugimi področji IO. Zato sta število in raznolikost publikacij, izobraževanj in promocijskih dogodkov, ki jih ponuja praksa, pomembno izhodišče in pobuda za razvoj sistemske ravni. Majhni, a redni, razpršeni in premišljeni koraki brez večjih donosov in izgub so skladni s policentričnim konceptom VITR, njegovo pozornostjo lokalni ravni, metodološko usmeritvijo $\mathrm{v}$ sodelovalno in skupnostno učenje, $\mathrm{s}$ sintezo in sinergijami sistemov znanja (npr. multi- in transdisciplinarnost), preobrazbo iz utilitarnih v odnosne motive ter celo upoštevanje transcendence, vsebovane v jeziku in vedenju (Virtanen idr., 2020). VITR v slovenskem IO torej obstaja, a je trenutno Pepelka. 
Prihodnost VITR ne izhaja iz zasebnih, ampak iz javnih potreb. Morda prinaša celo presenečenja, kar nakazujejo najnovejši kriteriji za VITR, ki bolj kot formalno izobrazbo upoštevajo avtohtone lokalne vzorce bivanja in delovanja tudi v strateških dokumentih (ICAE, 2020; UIL, 2020; Virtanen idr., 2020). Prenos težišča z (dragih) pozitivističnih pristopov, zasnovanih od zgoraj navzdol, k celovitejši zasnovi od mikrolokalnih skupnosti navzgor, nakazuje zahtevnost, pa tudi privlačnost VITR v prihodnosti ter se $\mathrm{v}$ celoti sklada $\mathrm{z}$ ugotovitvami analize, ki so jo v letu 2019 izpeljali strokovni delavci v IO pod okriljem Zveze izobraževalnih in svetovalnih središč (ZISS, 2019).

Razvitosti VITR torej ne sodimo po umestitvah v strateške dokumente, ki mu sicer določajo finančne in kadrovske možnosti, ampak po njegovih učinkih na zadovoljevanje javnega interesa $v$ najširšem smislu. Ne zanikamo poudarjene potrebe po dvigu bralne pismenosti in delu z ranljivimi ciljnimi skupinami (Resolucija, 2020), želimo pa poudariti strateško potrebo tudi po VITR, okoljskem znanju, veščinah in kompetencah. Teh ne potrebujejo le ranljive skupine, ampak vsi prebivalci Slovenije, k čemur nas že zavezujejo mednarodne pogodbe, npr. Pariški sporazum (Piciga, 2020). Izhodišče, argumenti in smer razvoja so jasni in so naslednji:

- Izhodišče so naravoslovne vsebine in mikrolokalna tradicija prilagoditev nanje, ker gre za kumulirane skupinske izkušnje, ki povezujejo tradicijo z vizijo prihodnosti. Poleg prakse bo izhodišče utrdila (trenutno neobstoječa) znanstvena podlaga, ki je pogoj, hkrati pa ne zagotovilo za kontekstualizirano razumevanje povezav in predvidevanje posledic izobraževanja (Lange, 2019, str. 1954).

- Argumentov za VITR ne postavljajo le mednarodni dokumenti, kot so UIL (2020), ICAE (2020) in drugi, trenutno upoštevani selektivno. Ključna je tudi percepcija potencialnih udeležencev, ki soustvarjajo interpretacije in skupaj iščejo rešitve. Ta bistveni konstitutivni element VITR ni redukcionističen, antropocentričen in individualističen primer t. i. bančniškega izobraževanja, ampak dinamičen in konstruktivističen ter izhaja iz informirane refleksije in skupinske kritične razprave, torej soustvarjene transformacije (npr. Burns, 2018), ki presega socialni konstruktivizem.

- Smer razvoja je policentrična izobraževalna ponudba, ki upošteva dinamiko sprememb, se osredotoča na odnose, soodvisnosti, ravnotežja, harmonijo, celovitost, integriteto in pravična razmerja. Cilj torej ni akumulacija racionalnega znanja, ampak na njeni podlagi obvladovanje dinamike odnosov, ki vključujejo moralnost, recipročnost in ustvarjalne sinergije tudi na višjih ravneh organizacije (O’Sullivan, 2002, v Lange, 2019, str. 1959). V tem vidimo vlogo strokovnih delavcev v IO v VITR, ki se že zdaj na različne načine ukvarjajo s povezovanjem, spodbujanjem ustvarjalnosti, mentorstvom in upoštevanjem tudi čustvenih, duhovnih in domišljijskih dimenzij učenja (Burns, 2018). Koncept skupnosti prakse, predstavljen v Ličen idr. (2017), je taki smeri razvoja najbližji in ne zanika domače definicije učeče se skupnosti (Bogataj in Pečar, 2013), na kateri temelji VITR in ki presega posameznika, a je nižja organizacijska raven od države. 


\section{SKLEPI}

Če je VITR v javnem interesu, ga velja razumeti precej širše, kot ga trenutno opredeljujejo nastajajoči strateški dokumenti za IO (npr. Resolucija, 2020). Prvo in ključno izhodišče za VITR je doživljanje narave. Tuji vzori so lahko navdih, niso pa kriterij, ker imata prednost avtentičnost in samoorganizacija, prilagojena konkretnim razmeram, ki so po planetu in tudi med evropskimi državami različne. Cilji VITR v IO, stabilni, odkar so bili postavljeni, so usmerjeni predvsem v razumevanje in zmanjševanje vpliva posameznika, skupin in skupnosti na naravo in soljudi, kar terja poznavanje nosilne sposobnosti okolja ter veliko družbeno odgovornost za nego horizontalnih in vertikalnih soodvisnosti (Jelen Mernik, 2016). Skupinske metode so primarne in tudi naši družbi niso tuje, zato jih velja uporabljati in nadgrajevati tudi v urbanih okoljih in javnem sektorju. Med ciljnimi skupinami gre posebna pozornost odločevalcem, šele za njimi izobraževalcem ter tistim, katerih ustanove so okoljsko problematične (npr. onesnaževalci zraka, vode, zemljišč, večji potrošniki energije). Bistveno je povezovati udeležence z različnim znanjem, interesi in stopnjo ozaveščenosti, ker tako zagotovimo ustvarjalni naboj za kakovostne refleksivne debate. Za vodenje takih skupin morajo biti strokovni delavci v IO vsebinsko usposobljeni, kar pa ne zadostuje za kakovosten VITR, saj slednji terja reference tudi na drugih področjih, npr. na področju vodenja skupinske dinamike. $\mathrm{Z}$ okoljskimi vsebinami je treba nadgrajevati oblike, ki že povezujejo več generacij, kakršni so denimo študijski krožki, četudi je medgeneracijskost le stranski učinek kakovostnega dela njihovih mentorjev (Cepin idr., 2019, str. 116).

Institucije in projekti IO naj v izhodišču ugotovijo svoj ogljični odtis ter ga poskusijo zmanjšati (z mobilnostnim načrtom, delitveno ekonomijo, samoevalvacijo delovanja, ki vključuje tudi način odločanja, in podobno). Kolektivna akcija, ki ni ideološka, ampak temelji na motivu razvoja lokalnega okolja znotraj njegovih nosilnih sposobnosti, v našem prostoru že poteka, zato tudi imamo možnost, da jo posodobimo in približamo urbanemu načinu življenja. VITR torej terja pogum za nenehno dinamiko odpiranja novemu ob hkratnem ohranjanju identitete. Čeprav si želimo hitrejšega sistemskega odzivanja na dosežke in pobude, je ena od razsežnosti VITR tudi potrpežljivost. Med drugim se nanaša na spoznanje, da izobraževanje ne spreminja le posameznika in družbe, ampak tudi vmesno, intermediarno raven kolektivne akcije. Ker so se teoretske podlage za slednjo razvile z motivom skrbi za okolje, so primerno izhodišče tudi za udejanjanje koncepta trajnosti in z njim za uveljavitev VITR.

\section{LITERATURA IN VIRI}

Anclin, M. (2020). Vzgoja in izobraževanje za trajnostni razvoj v izobraževanju odraslih - leto 2020. UPI Žalec.

Anclin, M. in Križnik, J. (2018). Tri, dva, ena - priložnost za trajnost še ni zamujena! UPI Žalec.

Anko, B. (2013). Pojem trajnosti in razvoj ideje. V N. Bogataj (ur.), Znamenja trajnosti (str. 17-20). Andragoški center Slovenije.

Anko, B., Bogataj, N., Gaberščik, A., Mastnak, M. in Ogorelec-Wagner, V. (2007). Temeljno usposabljanje za trajnostni razvoj. Andragoški center Slovenije. 
Anko, B., Bogataj, N. in Mastnak, M. (2009). Berilo o trajnosti. Andragoški center Slovenije.

Boeren, E. (2019). Understanding Sustainable Development Goal (SDG) 4 on "quality education" from micro, meso and macro perspectives. International Review of Education, 65(2), 277-294.

Bogataj, N. (ur.). (2013a). Znamenja trajnosti. Andragoški center Slovenije.

Bogataj, N. (2013b). Živimo trajnost. V N. Bogataj (ur.), Znamenja trajnosti (str. 168-180). Andragoški center Slovenije.

Bogataj, N. (16. 4. 2018). Razstava študijskih krožkov na Jakopičevem sprehajališču v Ljubljani. Andragoški center Slovenije. https://enovicke.acs.si/razstava-sk-v-ljubljani/

Bogataj, N. (2020). Delovno sodelovanje pri reševanju problemov v tehnološko bogatih okoljih primerjava med skupinama z visokimi in nizkimi dosežki. V P. Javrh (ur.), Delovno aktivni prebivalci z nižjimi spretnostmi (str. 59-71). Andragoški center Slovenije.

Bogataj, N. in Krč, J. (2018). An insight into forest owners' response to extreme events : a case of Postojna sleet in 2014 and bark beetles in 2015 and 2016. V Sustainable forest management for the future - the role of managerial economics and accounting: Book of abstracts (str. 73-75). Sveučilište u Zagrebu, Fakultet šumarstva i drvne tehnologije.

Bogataj, N. in Pečar, M. (2013). Skupnost, ki se uči - kaj je to? V N. Bogataj, M. Imperl in J. Prah (ur.), Študijski krožki kot prispevek k razvoju lokalne skupnosti (str. 9-11). JZ KTRC Radeče.

Bogataj, N., Piciga, D., Karba, R. in Rejec, P. (2016). Razširjeni program za trajnostni razvoj in zeleno gospodarstvo $v$ povezavi s podnebnimi spremembami: Končno poročilo. Andragoški center Slovenije.

Burns, H. (2018). Thematic Analysis: Transformative Sustainability Education. Journal of Transformative Education, 16(4), 277-279. https://doi.org/10.1177/1541344618796996

Carson, R. (1972). Nema pomlad. Državna založba Slovenije.

Cepin, M., Lajovic, F. in Bogataj, N. (2019). Medgeneracijsko sodelovanje v študijskih krožkih. V N. Bogataj (ur.), Študijski krožki: Iz korenin k novim izzivom za življenje v skupnosti [2., dopolnjena izd.]. Andragoški center Slovenije.

De Angelis, R. (2018). Entwining a Conceptual Framework: Transformative, Buddhist and Indigenous-Community Learning. Journal of Transformative Education, 16(3), 176-196. https://doi. org/10.1177/1541344617753071

Erčulj, J., Košmrlj, K., Sedmak, S. in Trnavčevič, A. (2010). Didaktični pristopi k vzgoji in izobraževanju za trajnostni razvoj: Zaključno poročilo o rezultatih opravljenega raziskovalnega dela v okviru CRP „Konkurenčnost Slovenije 2006-2013“. Univerza na Primorskem, Fakulteta za management.

Globalno učenje za spodbujanje trajnostnega razvoja v vzgoji in izobraževanju [Konferenca Zavoda RS za šolstvo]. (2012). https://www.zrss.si/objava/konferenca-globalno-ucenje-za-spodbujanje-trajnostnega-razvoja-v-vzgoji-in-izobrazevanju

Gobbo, Ž. (2011). Izobraževanje za trajnostni razvoj Slovenija: Poročilo raziskave. Focus, društvo za sonaraven razvoj.

Hardin, G. (1968). Tragedy of the commons. Science, 162, 1243-1248.

International Council for Adult Education. (2020). Adult Learning and Education (ALE) - Because the future cannot wait: Contribution of International Council for Adult Education (ICAE) to the UNESCOs' Futures of Education Initiative. https://bit.ly/2ObZrps

Jelen Mernik, A. (2016). Umestitev vsebin iz področja prilagajanja na podnebne spremembe ter njihovega blaženja v izobraževalne programe za odrasle. Andragoški center Slovenije.

Kleč, U. (23. 10. 2020). Primeri dobrih praks Alpske šole [Spletna predstavitev]. Biotehniški center Naklo.

Koulaouzides and Popović, K. (2017). Adult Education and Lifelong Learning in SouthEastern Europe: A Critical View of Policy and Practice. Sense Publishers. https://doi.org/10.1007/978-94-6351-173-5 
Lange, E. (2018). Transformative Sustainability Education: From Sustainable to a Civilization Leap. V M. Milana, S. Webb, J. Holford, R. Waller in P. Jarvis (ur.), The Palgrave International Handbook on Adult and Lifelong Education and Learning (str. 397-420). Palgrave Macmillan. https://doi. org/10.1057/978-1-137-55783-4_21

Lange, E. (2019). Transformative Learning for Sustainability. V W. Leal Filho (ur.), Encyclopedia of Sustainability in Higher Education (str. 1954-1966). Springer. https://doi. org/10.1007/978-3-319-63951-2_104-1

Ličen, N. (2015). Trajnostni razvoj: od teorije k praksi v izobraževanju odraslih: Preizpraševanje globalnega razvojnega modela kot izhodišče za načrtovanje zelenih izobraževalnih programov: Delovni zvezek za sodelovalno učenje. https://www.lu-ajdovscina.si/mma/trajnostni_razvoj_od_teorije_k_praksi_v_izobrazevanju_odraslih_gradivo_2015/2015090308170900/

Ličen, N. in Bolčina, B. (ur.). (2011). Neformalno izobraževanje za trajnostni razvoj: Priročnik za delo v andragoških skupinah. Ljudska univerza Ajdovščina.

Ličen, N., Fakin Bajec, J. in Ličen, M. (2015). Katero metodo naj izberem, da bo zeleno izobraževanje učinkovito? Ljudska univerza Ajdovščina.

Ličen, N., Findeisen, D. in Fakin Bajec, J. (2017). Communities of Practice as a Methodology for grassroots Innovation in Sustainable Adult Education. Andragoška spoznanja, 23(1), 23-39. http://dx.doi. org/10.4312/as.23.1.23-39

Maček, J. (2013). Gorski vinogradi, gorske skupnosti in gorske pravde. V N. Bogataj (ur.), Znamenja trajnosti (str. 57-67). Andragoški center Slovenije.

Manion, G., Biesta, G., Priestley, M. in Ross, H. (2011). The global dimension in education and education for global citizenship: genealogy and critique. Globalisation, Societies and Education, 9(3-4), 443-456. https://doi.org/10.1080/14767724.2011.605327

Marentič Požarnik, B. (2014). Vzgoja in izobraževanje za trajnostni razvoj - kje smo ob koncu desetletja VITR. Vzgoja in izobraževanje, 45(4), 5-13.

Marentič Požarnik, B. in Silan, D. (2015). Kaže, da je gradnja mostov moja usoda: Pogovor z ddr. Barico Marentič Požarnik, zaslužno profesorico Univerze v Ljubljani. Didakta, 25(3), 2-6.

Mohorčič, N., Sovdat, I. in Ličen, N. (2017). Sivka. Ljudska univerza Ajdovščina.

Možina, T. (2019). Sistemsko umeščanje delovanja študijskih krožkov. V Bistvo je očem nevidno: Kako obogateti: Zbornik tekstov o študijskih krožkih (str. 20-26). Andragoški center Slovenije.

OECD. (2016). A codebook. http://www.oecd.org/skills/piaac/Translated_HTML_si-SL.htm

Ostrom, E. (1990). Governing the Commons: The evolution of institutions for collective action. Cambridge University Press. https://doi.org/10.1017/CBO9780511807763

Pais, I., Provasi, G. (2015). Sharing economy: A Step Towards the Re-Embededness of the Economy? Stato e Mercato, 105(3), 347-378.

Piciga, D. (31. 1. 2017). Integral Conceptual Framework for a new Economic and Social Reality in Slovenia and Europe [3rd international conference Integral green Economy for a better World]. https:// www.trans-4-m.com/integral-societies/integral-slovenia/

Piciga, D. (4.-5. 6. 2020). The Future of Slovenia and Europe in a Turbulent World: Integrating Perspectives and Actualising Potentials on a Path of Sustainability [15 ${ }^{\text {th }}$ IRDO International Science and Business Conference: Social responsibility and current challenges 2020: Personal and social responsibility for sustainable future]. IRDO.

Piciga, D., Marentič Požarnik, B., Kolar, M. in Vovk Korže, A. (2016). Holistic education for sustainable development: Education as a key catalyst for an integral green Slovenia. V D. Piciga, A. Schieffer in R. Lessem (ur.), Integral green Slovenia : towards a social knowledge and value based society and economy at the heart of Europe (str. 192-206). Routledge. 
Polajnar Horvat, K., Smrekar, A. in Zorn, M. (2014). The development of environmental thought in Slovenia: a short overview. Ekonomska i Ekohistorija, 10(1), 16-25.

Popović, K. (2018). Agenda 2030 - a catalyst or a Procrustean bed for the community adult learning. V A. Marjanušić, A. Marušić in M. Mašić (ur.), Education 2030 \&Adult Learning: Global Perspectives and Local Communities - Bridges or Gaps? Agendas, Practice and Research (str. 10-11) [BGLALC 2018 Conference Programme Book]. Ustanova za obrazovanje odraslih Dante.

Posoški razvojni center. (23. 5. 2016). Od ponovne uporabe do Zero Waste (Zgodbe iz Slovenije) [Video]. YouTube. https://www.youtube.com/watch?v=1AXQxzYSoSs

Rejec, P. (ur.). (2008). Teden arhitekture - Korak naprej v kakovosti bivanja 2008. Posoški razvojni center.

Rejec, P. (ur.). (2009). Rož'ce z okusom. Posoški razvojni center.

Rejec, P. in Kutin, M. (2014). Neizkoriščeni potenciali alpske stavbne dediščine v luči trajnostne gradnje. Posoški razvojni center.

Rejec, P., Obid, E. in Gaberščik, D. (2013). Buoh dej dabra 2013-2014. Posoški razvojni center.

Resnik Planinc, T. in Ogrin, M. (2017). Vzgoja in izobraževanje za trajnostni razvoj. V B. Lampič in J. Zupančič (ur.), Raziskovalno-razvojne prakse in vrzeli trajnostnega razvoja Slovenije (str. 102-114) [Zbirka GeograFF, 9]. Znanstvena založba Filozofske Fakultete Univerze v Ljubljani. https://doi. org/10.4312/9789612379025

Resolucija o Nacionalnem programu izobraževanja odraslih v Republiki Sloveniji za obdobje 20132020 (ReNPIO13-20). (2013). Uradni list RS, št. 90/13 in 6/18 - ZIO-1. http://www.pisrs.si/Pis.web/ pregledPredpisa?id=RESO97

Resolucija o Nacionalnem programu varstva okolja za 2020-2030 (ReNPVO20-30). (2020). Uradni list $R S$, št. 31/20. http://www.pisrs.si/Pis.web/pregledPredpisa?id=ODLO1985

Sedmak, S. (ur.). (2009). Danes za jutri: razmišljanja o vzgoji in izobraževanju za trajnostni razvoj. Univerza na Primorskem, Fakulteta za management.

Sedmak, S. in Trnavčevič, A. (2009). Trajnostni razvoj in trajnostna potrošnja v kurikulu: Raziskava med dijaki in učitelji. V S. Sedmak (ur.), Danes za jutri: razmišljanja o vzgoji in izobraževanju za trajnostni razvoj (str. 77-96). Univerza na Primorskem, Fakulteta za management.

Skoberne, P. (2018, marec). Opredelitev trajnostnega razvoja in njegovih sopomenk s primeri in dilemami življenja po načelu trajnostnega razvoja [predavanje v sklopu temeljnega usposabljanje za trajnostni razvoj]. Andragoški center Slovenije.

Služba vlade za razvoj in evropsko kohezijsko politiko. (2018). Poročilo Slovenije za Agendo 2030. https://www.gov.si/assets/vladne-sluzbe/SVRK/Agenda-2030/Implementing_the_Agenda2030_update_2018.pdf

Smernice vzgoje in izobraževanja za trajnostni razvoj od predšolske vzgoje do univerzitetnega izobraževanja. (2007). Ministrstvo RS za šolstvo in šport.

Tengö, M., Hill, R., Malmer, P., Raymond, C. M., Spierenburg, M., Danielsen, F., Elmqvist T. in Folke, C. (2017). Weaving knowledge systems in IPBES, CBD and beyond - lessons learned for sustainability. Current Opinion in Environmental Sustainability, 26-27, 17-25. https://doi.org/10.1016/j. cosust.2016.12.005

Tilbury, D. (2015). Education for Sustainability: A Snakes and Ladders Game? Foro de Educación, 13(19), 7-10. https://doi.org/10.14516/fde.2015.013.019.000

Torkar, G. (2014). Learning experiences that produce environmentally active and infomed minds. NJAS Wageningen Journal of Life Sciences 69, 49-55. https://doi.org/10.1016/j.njas.2014.03.002

UNESCO. (1974). Recommendation concerning Education for International Understanding, Co-operation and Peace and Education relating to Human Rights and Fundamental Freedoms 
[18 ${ }^{\text {th }}$ session of the General Conference, 19 November 1974]. http://portal.unesco.org/en/ev.phpURL_ID=13088\&URL_DO=DO_TOPIC\&URL_SECTION=201.html

UNESCO. (2017). Education for Sustainable Development Goals. Learning Objectives. http://unesdoc. unesco.org/images/0024/002474/247444e.pdf

UNESCO Institute for Lifelong Learning. (2020). Embracing the Culture of Lifelong Learning: Contribution to the Futures of Education initiative. https://unesdoc.unesco.org/ark:/48223/pf0000374112

Virtanen, P. K., Siragusa, L. in Guttorm, H. (2020). Introduction: toward more inclusive definitions of sustainability. Current Opinion in Environmental Sustainability, 43, 77-82. https://doi.org/10.1016/j. cosust.2020.04.003

Vogrinc, J. (2008). Kvalitativno raziskovanje na pedagoškem področju. Univerza v Ljubljani, Pedagoška fakulteta.

Zakon o izobraževanju odraslih (ZIO-1). (2018). Uradni list RS, št. 6/18 in 189/20 - ZFRO. http://www. pisrs.si/Pis.web/pregledPredpisa?id=ZAKO7641

Združenje izobraževalnih in svetovalnih središč Slovenije. (2019). Povzetki proaktivne kavarne moderiranih omizij. https://www.ziss.si/ziss/novice-13482/povzetki-proaktivne-kavarne-moderiranih-omizij-13487/ 